\title{
TATBiKi GÜZEL SANATLAR YÜKSEK OKULU DEKORATiF RESiM BÖLÜMÜ EĞiTiMININ SEÇILMIŞ SANATÇILAR ÜZERINDEN TUVAL RESMINDEKI MALZEME KULLANIMINA ETKISI
}

\author{
THE EFFECT OF THE TATBIKI GÜZEL SANATLAR YÜKSEK OKULU (APPLIED FINE ARTS COLLEGE) DECORATIVE PAINTING \\ DEPARTMENT EDUCATION ON THE USE OF MATERIALS IN CANVAS PAINTING THROUGH THE WORKS OF SELECTED \\ ARTISTS
}

\author{
Z. Rüçhan Şahinoğlu Altınel* \\ DOI: 10.17490/Sanat.201559170
}

\section{Öz}

Bu makalede, Tatbiki Güzel Sanatlar eğitim sisteminin üç sanatçısı üzerinden tuval resmindeki farklı malzeme kullanımı incelenmektedir. Bu kapsamda Devlet Tatbiki Güzel Sanatlar Yüksek Okulu'nun eğitim sistemi sergilenmekte, mezun sanatçılarla ve ilk dönem öğretim üyeleri ile yapılan söyleşiler ve sağladıkları dökümanlar/yapıı görselleri üzerinden konu anlatılmaya çalışılacaktır. Yazıda, Devlet Tatbiki Güzel Sanatlar Yüksek Okulu mezunu sanatçıların tuval üzerinde malzeme kullanımı ile geleneksel tekniklere getirdiği farkılıkların incelenmesi amaçlanmaktadır. Anahtar kelimeler: Sanat eğitimi, resim, malzeme resmi, karışık teknik

\section{Abstract:}

In this article, the effect of the Applied Fine Arts College Decorative Painting Department education system on the use of different materials in canvas painting is studied through the works of three artists. Within this scope, the education system of the Applied Fine Arts College is exposed and the subject is explained using the interviews held with artists who graduated from the college as well as the first period lecturers and the documents/artwork images they provided. The purpose of this article is to study the material use of the graduates of the Applied Fine Arts College on canvas and the differences they brought to the traditional techniques.

Key words: Art education, painting, material painting, mixed technique

Türkiye'deki sanat eğitiminin geçmişi üç önemli okulla başlamıştır. IIlk sanat kurumu 1883 yılında eğitime başlayan ve bugünkü adıyla 'Mimar Sinan Güzel Sanatlar Üniversitesi' olan 'Sanayi-i Nefise' mektebidir. Okul, Osman Hamdi Bey tarafından Paris Ecole des Beaux- Arts modeline göre kurulmuştur.

İkinci kurum ise İsmail Hakkı Tonguç'un 1932 yılında Ankara'da kurduğu Gazi Eğitim Enstitüsü Resim-Iş Bölümüdür. Cumhuriyet'in erken yıllarında Anadolu'ya öğretmen yetiştirmek amacıyla böyle bir kurumun açılması gelecekçi eğitim politikalarının bir göstergesidir. Sanata ve eğitime yapılan bu ve benzer yatııımların daha sonraki eğitim örgütlenmelerinde de etkili olduğunu söylemek olanaklıdır. "Bir ulusun bütün ruhunun ve aklının sanatıyla ifade edildiği inancıyla, sanatı halkın hizmetine adayan ilk filozof John Ruskin'in öğretilerini hatıllatan bu tasarı, Halk Evleri ve Köy Enstitüleri'nin örgütlenmesine eklemlenir"' (1).
Türkiye'deki sanat eğitimi sisteminde farklı bir duruşla yer alan üçüncü kurum ise 1957'de İstanbul'da kurulan Devlet Tatbiki Güzel Sanatlar Okulu'dur. Devlet Tatbiki Güzel Sanatlar Okulu'nun kurulması ile ilgili çalışmalar Mesleki ve Teknik Öğretim Genel Müdürlüğü'nün (Müdür- Ferit Saner) 1 Kasım 1955 tarihli kararı ile başlamıştır. Devlet Tatbiki Güzel Sanatlar Okulu'nun ilk Müdürlüğü'ne 1956 yılında Doç.Dr. Ahmet Sabri Oran (d.1905-0̈.1972) getirilmiştir. Kurulum sürecinde Oran 1929-31 yılları arasında eğitim aldığı Stuttgart Technische Hochschule'deki hocası, ITÜ Mimarlık Bölümü'nün kuruluşunda görev almış olan Prof. Paul Bonatz (d. 1876- 0̈. 1956)'dan destek almıştır. Prof. Bonatz Tatbiki'nin kuruluşunda çalışması için öğrencisi de olmuş olan Prof.Dr. İng. Adolf G. Schneck'(d.1883-0̈.1971) i önermiş ve Tatbiki'yi kurma görevi, Avrupa'da bazı Bauhaus okullarının kuruluşunda da yer alan Schneck'e verilmiştir. Okul Beşiktaş'ta Dolmabahçe Sarayı'nın bahçesinde bulunan, önceden Baltacılar Dairesi adıyla anılan binada eğitime başlamıştır.

1961 yılı, T.C. Milli Eğitim Bakanlığı Mesleki ve Teknik Öğretim Müsteşarlığı, İstanbul Tatbiki Güzel Sanatlar Okulu Yönetmeliği'nde yeralan Devlet Tatbiki Güzel Sanatlar Okulu'nun kuruluş amacını,

"Madde 1- Tatbiki Güzel Sanatlar Okulu;

a) Birinci devresinde; memleket sanayiinin intiyacı olan ve artistik eğitim ile birlikte mesleğinin tekniğini üstün bir seviyede elde etmiş uygulayıcı sanatkar yetiştiren

b) İkinci devresinde endüstri ve el sanatlarının muhtaç olduğu mesleğin tekniğine hakim, yeni buluşlar meydana getirmeye muktedir mütehassıs elemanlar yetiştiren iki devreli bir okuldur..." (2) göstermektedir.

Tatbiki Güzel Sanatlar Okulu'nun amacını sanat ve zanaatın endüstriyel üretimle birleşimi diye özetlersek bunu Mimar Sinan Güzel Sanatlar Üniversitesi'nin model almıș olduğu, Beaux-Arts akademik geleneğinden ayrılığı olarak da niteleyebiliriz. Tatbiki Güzel Sanatlar Okulu'nun tuval resmindeki farklı malzeme kullanımına etkisine geçmeden önce model aldığı Bauhaus eğitim sistemine ve öğretilerine genel olarak değinmek yerinde olacaktır.

1919 yılında Walter Gropius (d.1883-0̈.1969) tarafından Almanya, Weimar'da 'Stattlich Bauhaus' adıyla kurulmuştur. "Gropius bu okulda zanaatçıların ve sanatçıların eğitiminde ve üretiminde birlikte çalıșmasını öngörmüş, güzel sanatlar ile uygulamalı sanatlar arasındaki ayrımı yok etmeyi amaçlamıştı”" (3). Amaçlanan "...öğrencinin kişisel eğilimlerini 
ve doğal yeteneklerini tanımaları ve geliştirmelerini sağlamakıı" (4). Bauhaus eğitiminde öğrenciye 'keşif ve buluş' yaptırmak ana ilke olmuştur. "Günümüzde Bauhaus ilkeleri üzerine temellenen çok sayıda sanat ve tasarım okulu bulunmaktadır" (5). Bu kurumlardan biri de Devlet Tatbiki Güzel Sanatlar Okulu'dur. Bauhaus'u model alan Tatbiki Güzel Sanatlar Okulu'nun kuruluşunda yer alan Dekoratif Resim, Tekstil, Mobilya ve İç-Mimarlık, Grafik, Seramik ilk bölümleridir. Kurulan bu ilk bölümlerin programlarının ve işlevlerinin Bauhaus okulunun modeli ve eğitim sistemi ile paralellik kurduğu gözlemlenmektedir. Gelişmekte olan yeni Cumhuriyet'in fonksiyonel ve estetik gereksinmelerine cevap arayan bir kurum görünümündeki okulun "Gerek zanaata verilen önem, gerek pedagojik bakış açısı, gerekse sanayi ile insanı birleştirme çabası göz önüne alındığında Bauhaus modeli Cumhuriyet ideolojisinin akılcı, yenilikçi, bütün insan modeline denk düşüyordu" (6).

Marmara Üniversitesi Güzel Sanatlar Fakültesi Fotoğraf Bölümü Öğretim üyelerinden Prof. Barbaros Gürsel Tatbiki'de almış olduğu eğitimi ve öğretim üyelerini "Okulumuz benim serbest çevirim ile "BAĞEVI" (Bauhaus) idi. Orada kalır, çalışır, çapalar, çabalardık... Bütün bu isimler, sonuna kadar deneyciliği, yaratıcılığı (disiplinli düşünmek ile) ve bol bol malzeme harcayarak araştırmacılığı öğretti." (7) diye açıklamaktadır. Bugün Resim ve Heykel Müzeleri'nde gördüğümüz ya da özel koleksiyonlarda izlediğimiz yapıtlarda tuval üzerine yağlıboya tekniğinin yetkin örneklerini görmekteyiz. Bu yazıda Tatbiki mezunu sanatçıların malzeme kullanımı ile geleneksel tekniklere getirdikleri farkıııkların incelenmesi amaçlanmaktadır. Kuruluşundan 14 yıl sonra 1971 yıında 'Devlet Tatbiki Güzel Sanatlar Yüksek Okulu' (TGSYO) olarak değiştirilen bu kurumun Dekoratif Resim Bölümü eğitim sisteminin tuval resmindeki farklı malzeme kullanımına geçmeden bölümün tarihçesine kısaca göz atmak yerinde olacaktır.

Kurumun geçmişi ile ilgili sınırlı sayıda kaynak olduğu için, diğer taraftan yazıı bazı bilgilerle sözlü bilgiler arasında çelişkilerle karşılaşıldığından Tatbikili mezun sanatçılarla ve ilk dönem öğretim üyeleri ile yapılan söyleşiler ve sağladıkları dokümanlar/ yapıt görselleri üzerinden konu aktarımaya çalışılacaktır. Tatbiki'nin kuruluş yıllarında öğretim üyeliğ yapmış olan, Stutgart Güzel Sanatlar Akademisi mezunu Frank Mezger, Herwig Schubert, Hans Baurle ve Tatbiki mezunu öğretim üyelerinden Erol Eti, Metin Şahinoğlu, Nevzat Yüzbaşıoğlu, Hüsamettin Koçan, Tayfun Erdoğmuş ve mezunlardan Murat Morova yazıya katkıda bulundular.

Stuttgart Güzel Sanatlar Akademisi'nde öğretim üyesi olan Schneck, Tatbiki'nin ilk öğretim üyelerini de bu kurumdan seçmiştir. Bütün bölümleri ortak bir platformda birleştiren, birinci sınıftaki en önemli ders Frank Metzger'in (d.1929) verdiği Temel Sanat Eğitimi'dir. 1957'den 1964'e kadar kurumda çalışan Frank Metzger'in öğrencilerine çeşitli malzemelerle (cam, ip, ahşap, metal, tel vs.) ve üç boyutlu uygulamalarla yaptırdığı deneysel çalışmalar farkı malzeme kullanımına geçişteki en önemli temellerden birini oluşturmuştur.

Frank Metzger o yıllarda yapılan çalışmaları aşağıdaki cümle ile özetlemektedir.

"57 yıl önce başladığımız görsel süreç, grafik programları, CAD vs. ile bugün gerçekleştirilebilenlerin sadece küçük bir parçasını kapsamaktadır (bütünleşik uygulama ve tasarım için bir temel oluşturan kontrastlar, varyasyon, kombinasyon, devinim, ritim, düzenlemeler, grid sistemi, kinetik, bilişsel ve sezgisel yaklaşımlar gibi sentaktik değerlerin tüm parametresinden bahsetmekteyim). Bu, hem uygulamalı tasarım hem de Güzel Sanatlar için hala heyecan verici bir konudur..."(8).

1973 yılı T.C. İstanbul Tatbiki Güzel Sanatlar Yüksek Okulu Eğitim-Öğretim Planları Broşüründe Temel Sanat Eğitimi dersinin amacl; " ...öğrencileri yeni çıkışlara, yeni deneyişlere ve olanaklara yönelten; onlara yeni bir bakış ve görüş sağlayan, onların her çeşit yaratıcı ve yapıcı güçlerini geliştiren, kişisel sanat yeteneklerinin yön ve gücünü ortaya çıkaran bir temel eğitim olarak bütün bölümlere uygulanır." (9) diye açıklanmıştır.

"Tatbiki'de yaratıcı birey yetiştirmeyi amaçlayan yeni bir eğitim metodu uygulanır. Bu metod, dünyada ilk kez Almanya'da kurulan Bauhaus'ta ele alınmıştır"(10). 1973 yılı planında öğrencilere kazandırılmak istenen bireysel yaratıcılığın ve deneyselliğin Tatbiki'nin Bauhaus ile devam eden bağını göstermektedir. Kurum öğretim programıyla farklı malzemelerle deneysel çalışmaları önererek sanat ve tasarım süreçlerindeki değişimlerde etkili olmuştur. Bauhaus eğitim ilkelerinin Tatbiki üzerindeki etkilerini bu derste yapıımış deneysel öğrenci işlerine ait görsellerden izlemek mümkündür (Resim 1-5).

Tatbiki Güzel Sanatlar Okulunun ilk yıllarında diğer bir etkili isim Buluş Kompozisyon ve Modelden Resim dersleri için görevlendirilen Herwig Schubert'dir (d. 1926). 1973 yılı T.C. İstanbul Tatbiki Güzel Sanatlar Yüksek Okulu Eğitim-Öğretim Planlarında dersin amacı "... resim ve şekillendirme eğitiminde yaratıcı anlatım dilinin kazanılmasıdır." (11) şeklinde yer almıştır.

Dersin metodu için ise "ikinci sınıfta başlayan bu derste akademik kurallara kaçmadan gününe özgü anlatımlara varabilmesi için öğrenciye form ve renk ilişkileriyle bunların anlatım olanakları araştıııcı açıdan aktarııır. III. sınıfta resim mekân ilişkileri kurularak kompozisyon fikri geliş̧irilir. Son sınıf proje yılı kabul edilerek duvar resmi çalışmalarına ağırlık verilmelidir." (12) yazmaktadır.

Tatbiki Güzel Sanatlar Yüksek Okulu'nda Dekoratif Resim Bölümü'nü ayırıcı bir kimlikle konumlandıran derslerden Duvar Tekniklerine Giriş, Duvar Dekorasyonu ve Tatbikatı derslerini 1958-62 yılları arasında Prof. Schneck'in seçtiği öğretim elemanlarından Hans Bauerle (d.1931) vermiştir. Sanat ve Tasarım Eğitiminde Tatbiki Güzel Sanatlar Okulu Gerçeği adlı kaynakta Prof. Schneck Bauerle için "Resim Bölümünün öğrencileri, pratik eğitimlerini, öğretim elemanı Her Bauerle'den alabilecekler. Çünkü Her Bauerle, duvar tekniklerinin hepsine hakim durumdadır." (13) demektedir.

1973 yılı T.C. İstanbul Tatbiki Güzel Sanatlar Yüksek Okulu Eğitim-Öğretim Planları Duvar Dekorasyonu Teknikleri dersinin amacı "Mimaride bütüne varılabilmesi için mekân değerlendirmesine katkıda bulunacak çalışma ve uygulamaların yapıımasıdır." (14) cümlesiyle belirtilmektedir. 1972 yılı İstanbul Tatbiki Güzel Sanatlar Yüksek Okulu broşürünün 


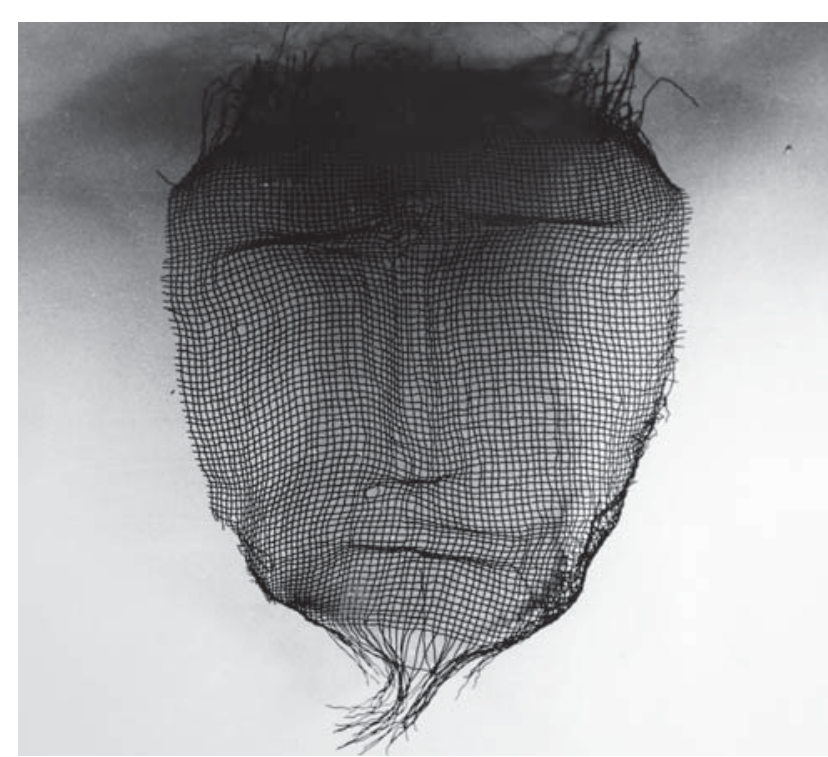

Resim 1. Temel Sanat Eğitimi dersi öğrenci çalışması, Frank Metzger Arşivi.

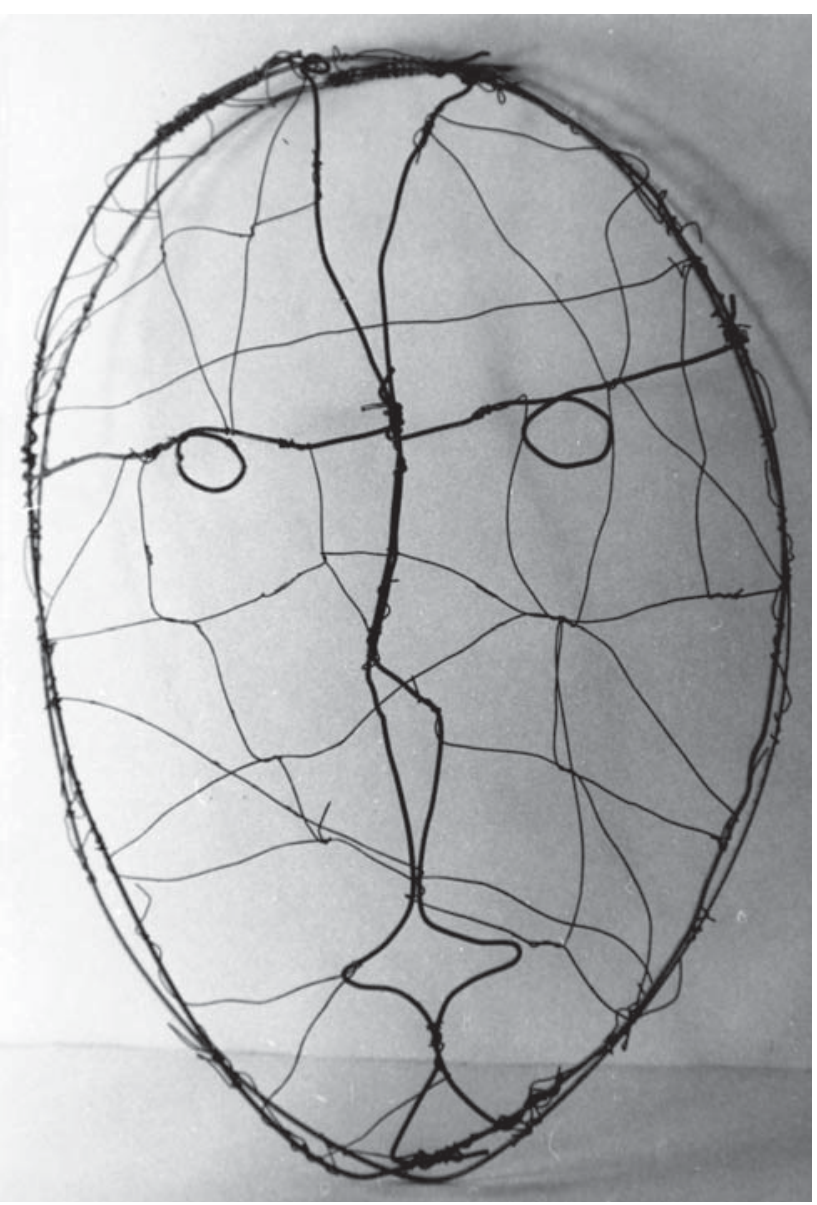

Resim 2. Temel Sanat Eğitimi dersi öğrenci çalışması, Frank Metzger Arşivi.
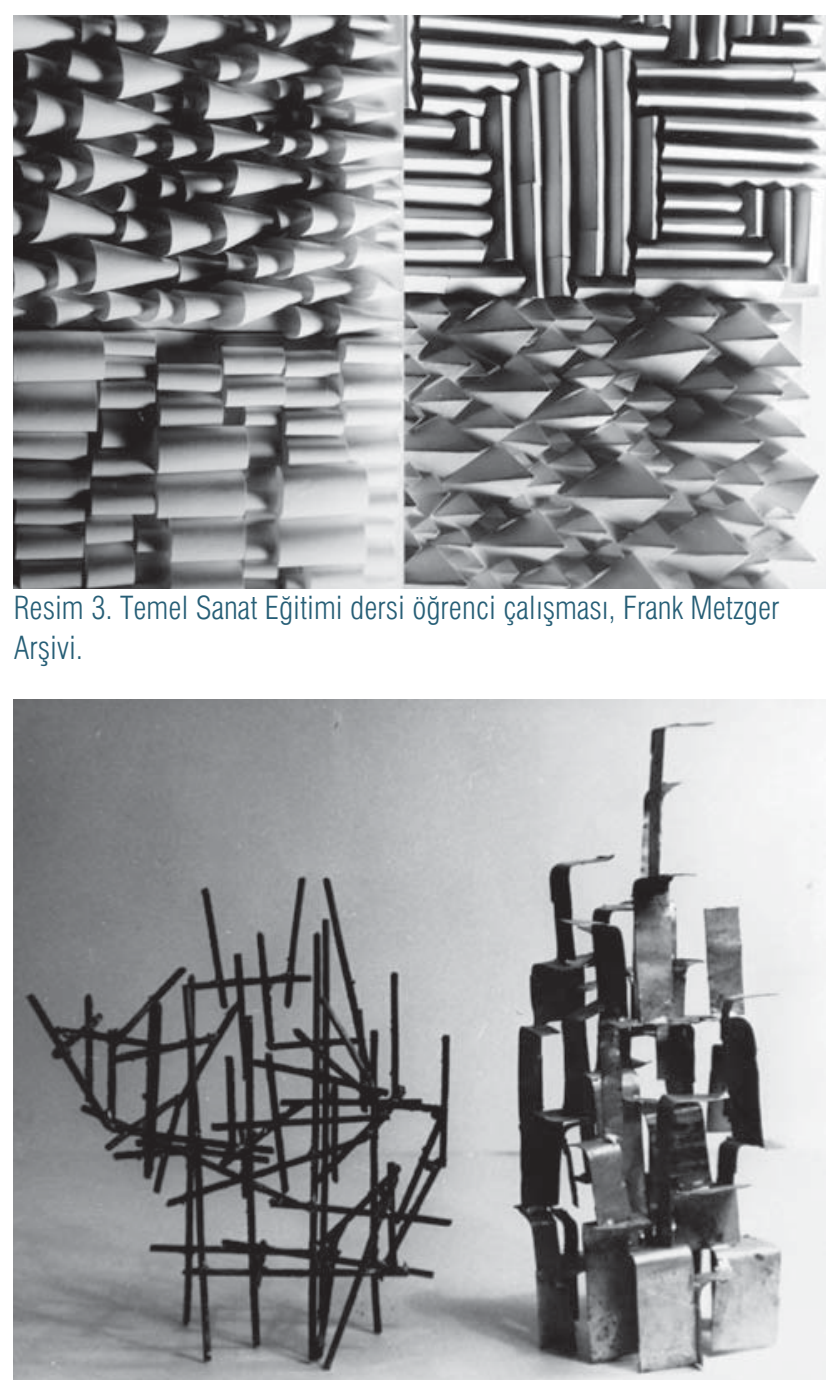

Resim 4. Temel Sanat Eğitimi dersi öğrenci çalışması, Frank Metzger Arşivi.

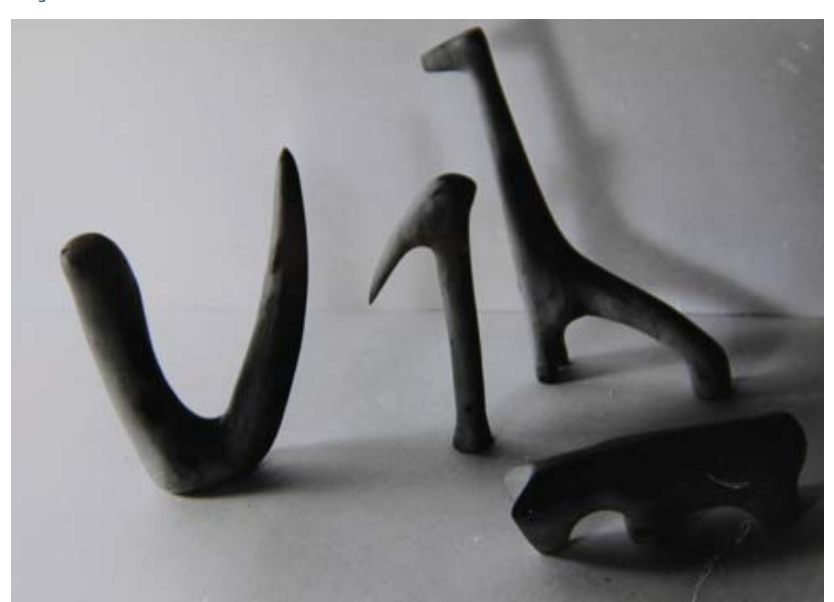

Resim 5. Temel Sanat Eğitimi dersi öğrenci çalışması, Frank Metzger Arşivi. 


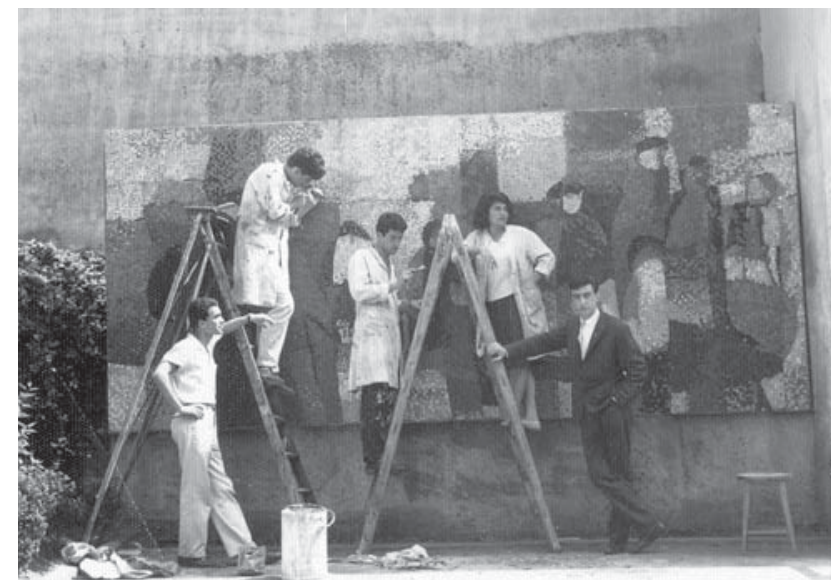

Resim 6. Duvar Resmi Teknikleri Dersi'nde öğrenciler çalışırken, Hans Bauerle Arşivi.

"Henüz var olmayan şeye biçim vermek' başlıkı giriş yazısında, "Okulda öğrencilere hazır biçimleri öğretmek veya taklit ettirmek diye bir yol yoktur. Öğrenci kendisi buluşa ve yaratmaya sevkedilmekte ve yaratabildiği değerlerin bilincine varmasına yardımcı olunmaktadır." (15) denilmektedir. Yapılan çalışmalarda form, renk, yüzeysel anlatım teknikleri gibi konular çağın sanat anlayışına koşut bir yaklaşımla irdelenmiştir (Resim 6-8).

Temel Sanat Eğitimi, Buluş Kompozisyon, Duvar Tekniklerine Giriş, Duvar Dekorasyonu ve Tatbikatı derslerinde alınan bilgiler ile kuvvetlenen öğrencilerin malzemelerle özgürce deneyler yapmaları, onları tuval resminde yeni teknikleri deneme konusunda cesaretlendirmiştir.

Bauhaus etkisiyle Dekoratif Resim Bölüm programın içeriği ilk yıllarında ağırlıklı olarak tekniğe ve deneyselliğe dayanan derslerden oluşmuştur. Tatbiki'nin kuruluşundan beri eğitim programında değişiklikler olmasına karşın bölümün derslerinin iki ana eksen üzerinden yürüdüğü gözlemlenmektedir.

Tatbiki döneminde Buluş Kompozisyon adı altında yapılan ders Resim Sanatı Dersine evrilmiş, Duvar Dekorasyonu adı altında yapılan ders ise 20. yy. sanatının değişken yapısına benzerlik gösterecek biçimde kendi içinde bölünerek Seçimlik Atölyelere dönüşmüştür. Bugün Seçimlik Sanat ve Tasarım dersleri adını alan atölyeler; Cam Sanatı, Duvar Resmi, Özgün Baskı Resmi ve Malzeme Resmi'dir. Tablo.1 tarihsel sıraya göre bu dersleri ve dersleri veren öğretim üyeleri göstermektedir.

Kuruluşundan beri kurumda verilmiş olan Temel Sanat Eğitimi, Duvar Dekorasyonu dersi ve halen verilmekte olan Seçimlik Sanat ve Tasarım dersleri, mezun sanatçıların tuvallerinde farklı malzeme arayışlarına yönlenmelerinde etkili olmuştur. Türk resim sanatında tuval resmindeki geleneksel yaklaşımı kırarak, malzemeyle kurdukları iletişimi özgün kimliklerle yapıtlarına yansıtan Tatbiki Dekoratif Resim bölümünden mezun, öncü sanatçılarımızdan Hüsamettin Koçan, Tayfun Erdoğmuş ve İç Mimarlık Bölümü'nden mezun Murat Morova'nın resimleri üzerinden ve aktardıkları bilgilerin katkılarıyla konu irdelenecektir.

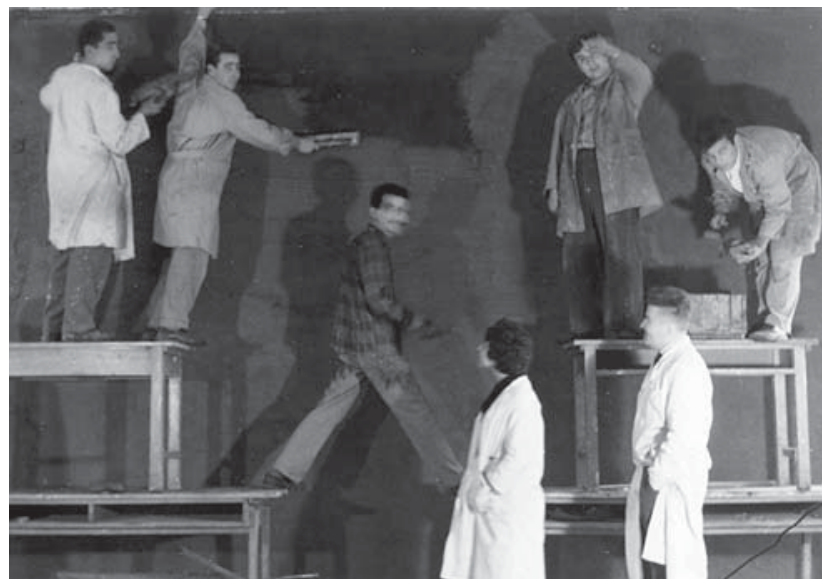

Resim 7. Duvar Resmi Teknikleri Dersi'nde öğrenciler çalışırken, Hans Bauerle Arşivi.

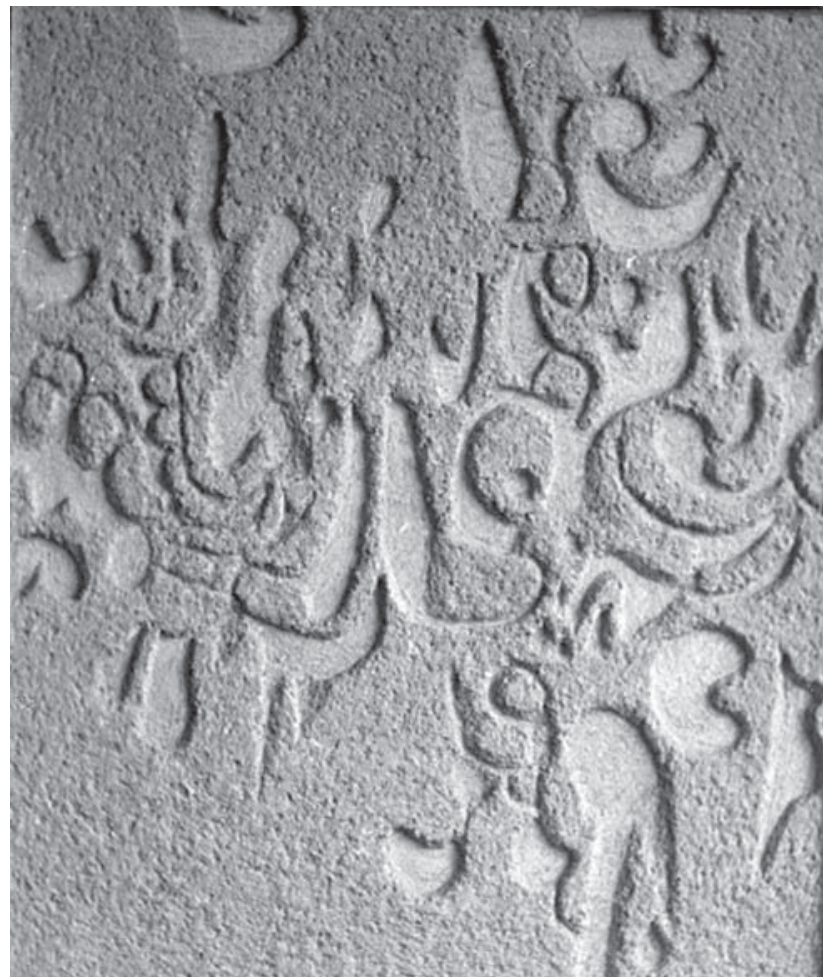

Resim 8. Duvar Resmi Teknikleri Dersi öğrenci çalışması, Hans Bauerle Arşivi.

1969-1970 eğitim ve öğretim yılında Tatbiki'den mezun olan Hüsamettin Koçan'ın (d.1946) üretim sürecine baktığımızda 80'li yıllarda pentür çaış̧maları yaptığını görmekteyiz. 0 yıllar ve öncesi hakkında Koçan; "Ben öğrenciyken pentür yapmadım. Rölyefler, scrafitolar yaptım ve mezun olduktan sonra uygulama alanı da bu malzemeler üzerinden gitti; çünkü mimariye resimler yaparak hayatta kalmaya çalışıyorduk. 0 sırada resim de satılmıyordu"(16) demektedir. 80'lerde küçük küçük pentürler yapan Koçan bu çalışmaları biraraya getirerek, bunlarla Anadolu arasında bağlantı kurmaya çalışmaktadır. Bu yıllarda 'Asılı Resimler Açısından Halk 
Resimleri' başlıkı asistanlık yeterlik tezini bitirmesi, 90'lara geldiğinde Anadolu kültürüne olan ilgisi ve bu konudaki araştırmalarının da etkisiyle Anadolu'nun Görsel Tarihi- Fasikül-1 (1993) serisine başlamıştır. Bu tarihten sonra sanatçının tuvallerinde pentür azalırken, malzeme kullanımı ağırlık kazanmıştır. Bu seri ile tuval üzerine kullanmaya başladığı ve bugüne kadarki üretiminde başat malzeme olan çamur (toprak) girmektedir. "Uzaktan bakışla 'yeryüzü kabuğu olarak tanımladığımız toprak, öte yandan da coğrafi olduğu kadar doğasal ve kültürel anlam çoğulluğuyla, Hüsamettin Koçan'ın önemli sanatsal gereçlerinden biridir ve resminin alt yapısını oluşturur" (17).

Osmanlı-Fasikül II (1994) serisinde ise Koçan, tuval üzerinde toprak, yaprak, mürekkep ve kâğıt kullanmıştır. Hüsamettin Koçan Selçuklu- Fasikül III (1995) serisinde kasnağı kaldırarak direk olarak tuval bezi üzerine çalışmış ve yapıtlarında tuvalin klasik kullanımına ait algıyı değiştirmiştir (Resim-9). Koçan tuval bezi üzerine Selçuklu formlarını çamurla oluşturmakta, kurutmakta, çatlamasını beklemekte, poli-izolan (poroz doldurucu) sürmekte, sonrasında da renklendirmektedir. Ayrıca yapıtları Ioş ve nemli bir mekân olan Alanya tersanesinde sergileyeceğinden üzerini mumla kaplamıştır. Mum hem yapıtları nemden korumakta, hem de kasnağı olmayan işlerin katı bir halde durarak sergilenmelerini sağlamaktadır. Kendisiyle yapılan bir söyleşide bu durumu "Anadolu'da muskaları ve başka nesneleri korumak, kimi Selçuklu gömülerinde ölü sultanları geleceğe bozulmadan aktarmak için kullanılan- mum ile kapladı." (18) cümlesiyle vurgulamaktadır. Koçan bir anlamda Selçuklu'nun geleneklerinden referans alarak aynı ritueli yapıtlarında da uygulamaktadır.

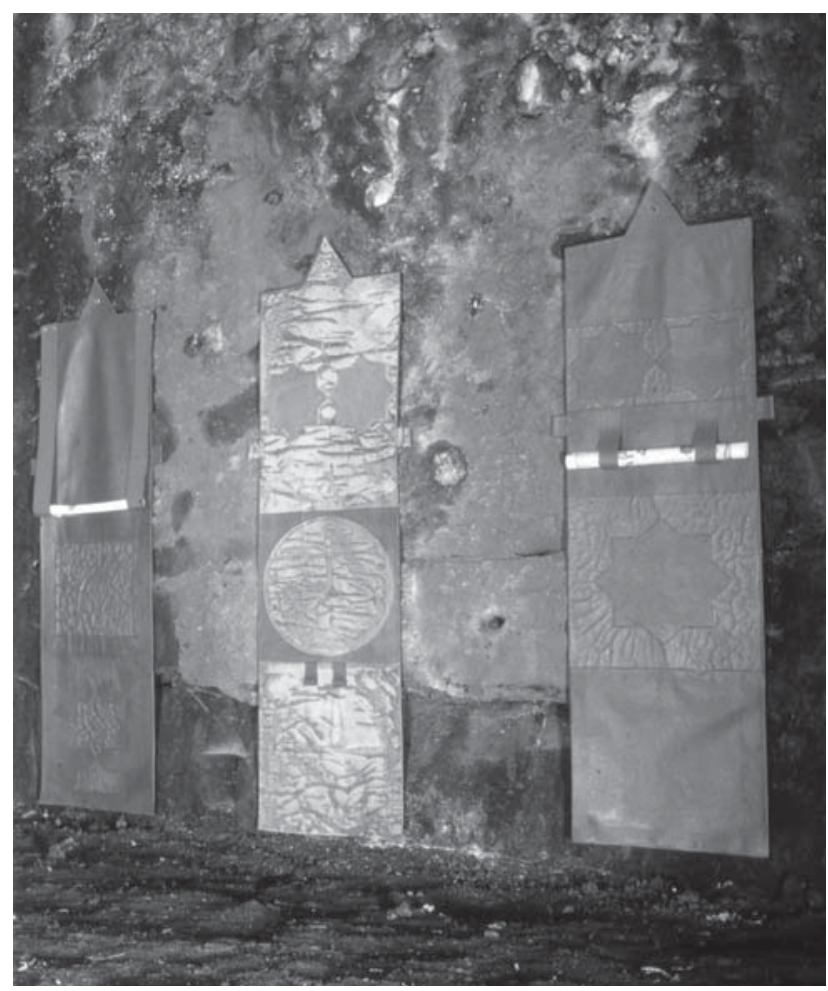

Resim 9. Hüsamettin Koçan, Selçuklu- Fasikül III,1995, Hüsamettin Koçan'ın izniyle.

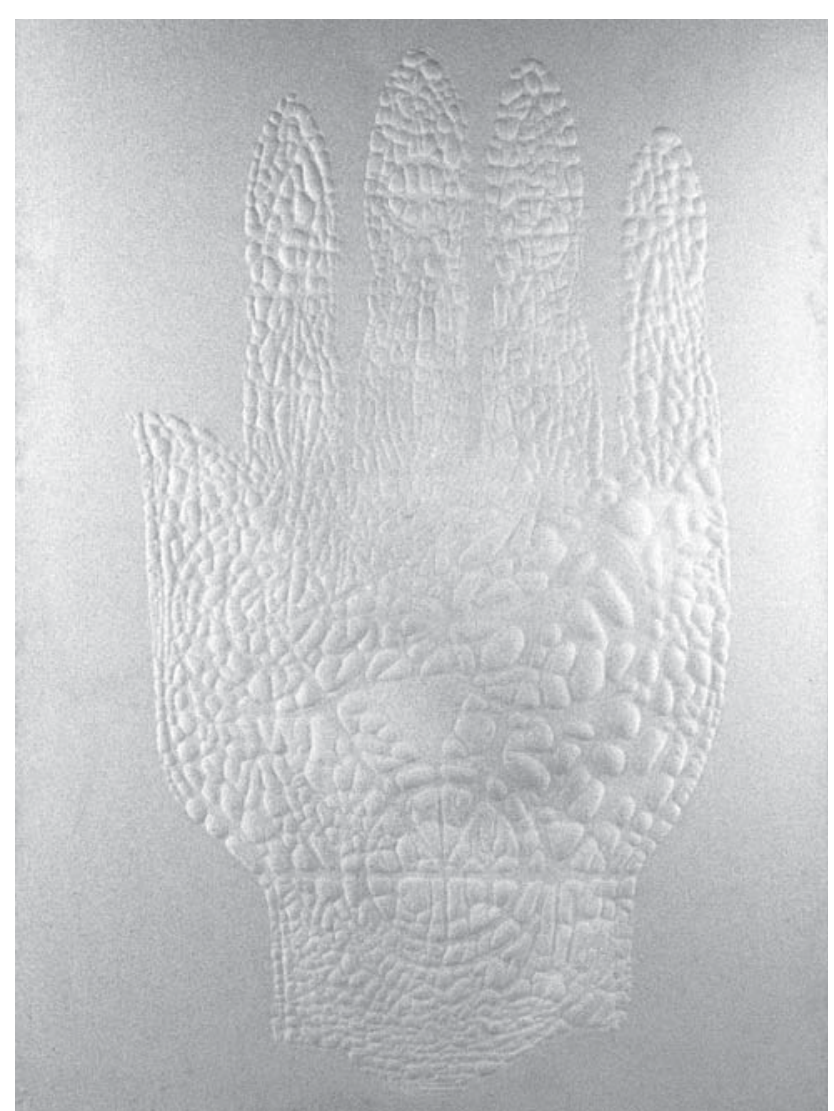

Resim 10. Hüsamettin Koçan, Körler için Resimler, Tuval üzerine karışık teknik, 2004, Hüsamettin Koçan'ın izniyle.

Koçan'ın malzeme ile ilişkisini yansıtan diğer bir sergi, Efkar Kırıkları'dır (2000). Dragoslu olmayıp, içip, efkarlanıp atmış oldukları şişelerin kırıklarından yola çıkan bu sergide kavram, Koçan'ın Dragos sahilden toplamış olduğu cam kırıkları üzerinden aktarılmaktadır.

Körler için Resimler Serisi'nde (2004) Koçan, malzemenin yarattığı dokunsal duygu üzerinden görme engellilerle çalışmaları arasında iletişim kurmayı amaçlamışıı (Resim 10). Koçan kavramı ileten dokunsal plastik etkileri yaratmak için çamuru doyurulmamış tuvalin arkasından sürmekte, kuruyup çatlamasını beklemektedir. Bu suretle tuvalin ön yüzünde plastik etkiler elde ederken tuvalin arkasındaki ana malzemeyi poli-izolan (poroz doldurucu) ile sabitlemektedir. Diğer taraftan Hüsamettin Koçan, bu sergideki çalışma yöntemi ile camaltı halk resmi arasında bağ da kurmaktadır. "Bu dizide de camalı resimlerinde olduğu gibi sanatçı, göz ile kendi arasında bir perde gibi tuvali koyar ve kendini geriye, geçmişe, yokluğa saklar. Eylem arka yüzde gerçekleşmiştir ama biz, ön yüzeye yansıyanları izleriz" (19).

Koçan malzeme olarak kullandığı çamur için, "Ben Anadolu'yu anlatıyorum, Anadolu bir kara parçası, onun mekânı niçin çamur olmasın? Ondan sonra oturdum, çamur nasıl kullanılmış, kerpiç nası yapılmış ve korunmuş araştırdım. 0 süreci yeniden geri dönerek öğrendim."(20) demektedir. Bu süreçten sonra Anadolu'daki geleneksel kerpiç yapımın- 
dan etkilenerek başat malzemesi çamura, kıl katarak kullanmaya devam etmektedir

Tuz Tadı (2006) başlıklı sergisinde slikonu tüm yüzeyi kaplayan bir malzeme olarak kullanan Koçan gene halk sanatına göndermeler yaparak izleyici ile kavramı anlatan diğer malzemeler arasına şeffaf bir tabaka koymaktadır. "...tekniği devam ettirmenin, korumanın yanı sıra geleneksel camaltı resimlerinin izleyiciye yarattığı 'başka/öte mekânda olma' duygusunu da yaratmayı amaçlar. İster camaltı, isterse sır altı tekniği olsun, ona dokunan ya da onu gören tarafından bir uzakta olma hissi yaratır." (21).

Hüsamettin Koçan ile Mayıs 2014 tarihinde yapılan röportajda günümüze kadar uzanan sanatsal üretiminde malzemeyle olan dialoğunu; "Çamur girdi, çamurla birlikte mumlama girdi, ondan sonra bu uzadı uzadı, pullar, kağıtlar, slikon girdi ve bütün bunlar benim sanatsal arka planımda yer alan yapılar. Halk resimleri ile ilgili çalışı̆ğım için camaltı resimlerin öyküsü benim açımdan çok ilginç. Slikon camaltı geleneği ile girdi resimlerime. Altı ay uğraşıı bu malzemeyi ehlileştirmek için. Bir malzemeyi yönetmeyi öğreniyorsunuz. İçinde bulunduğunuz toplumu dinleyerek, anlayarak, çağın malzemesi ile çağın duygusuyla ona yaklaşırsanız, 0 ister istemez sizi belli bir yenilenmeye doğru götürüyor. Yani gözüken malzeme çeşitliliği de odur. Malzeme kullanımımın arkasında tabiki Tatbiki geleneğinin büyük gücü var..." (22) diye özetlemektedir.

1979 yılı Tatbiki Güzel Sanatlar Yüksek Okulu mezunlarından Tayfun Erdoğmuş'un sanatsal üretimine bakıldığında sanatçının tuval üzerinde geleneksel malzemenin dışına çıkı̆ğı görülmektedir. 1970'lerde tuvallerinde, Türkiye'de zor bulunan bir malzeme olan akrilik boya kullanmaktadır. Akrilik boyanın sanatçıya getirdiği yenilik, hızlı ve üstüste çalışma olanağıdır. Malzemeyi transparan bir şekilde üstüste kullanması katmanlar yaratma düşüncesini doğurmuştur. Sanatçı bu süreçte bir takım katmanları örtüp, üstünü tekrar boyayarak, sonra ara katmanları tekrar sökerek arkadaki katmanları göstermiştir. 80'li ve 90'lı yıllarda bu tekniğini daha da geliştiren Erdoğmuş, lateks ve benzeri malzemelerle tuvali maskeleyip, üstünü boyayıp, tekrar açarak ve bunun sürekli tekrarlanması ile tuvallerini oluşturmuştur. Daha sonraki yıllarda kum, kil, toprak gibi doğal malzemeler akullanmaya başlayan Erdoğmuş, resimlerinde fotoğrafı da dahil ederek bir çölleşme yaratmaya çalışmıştır. Tayfun Erdoğmuş, bu dönemden sonra üreteceği işler hakkında "İnsanlığın kültür katmanlarının bir şekilde yıkııp, kapanıp, yeniden açılmasıyla yeniden bir topoğrafyayı, yeni bir coğrafyayı oluşturması düşüncesi kâğıt resimlerimin ana teması olmuştu..." (23) demektedir. Erdoğmuş sonraki çalışmalarında boya kullanmayı tamamen bırakmışıı.

Kullandığı transparan malzemenin içine bitki dünyasından seçtiği yaprakları, çiçekleri gömerek katmanlar oluşturmaya başlamıştır. Erdoğmuş resimlerindeki bitki kullanımı ile ilgili "...Resimlerimdeki bitki kullanımı hazır form olma odakııdır ve bitkinin çeşitli anlamlarına, semboliğine yaslanmadan yüzeyde tekrar nesnesi olarak yer alır... Çini'den taş işçiliğine uzanan bitki kullanımının mimariye eklemlenen, mimaride yaşayan çoğunlukla dekoratif diye önemsenmeyen arkasındaki düşüncenin-yaklaşımın algılanmadığı bu yapıya yeniden bakma niyetidir..."(24) demek- tedir. Bir başka deyişle “Tayfun Erdoğmuş'un sanat anlayışı, geleneksel olanla çağdaş olan arasında kurulan biçimsel ve içeriksel dengeyle yepyeni bir görsel dil yaratma çabası olarak özetlenebilir" (25).

Bu işleri ile pentürün alışılmış yapısının tamamen dışına çıkan sanatçı, tuvale ne fırça ile boya sürmekte, ne şablonlar kesip içini boyamakta, ne de pistole ile boya püskürtmektedir. Sanatçı işlerinde başat malzeme olan çiçekleri çok büyük boyutlardaki defterler arasında kurutmaktadır. Erdoğmuş, çeşitli seyahatler yaparak topladığı veya bazen satın aldığı çiçeklerin renklerini tamamen kaybedebilmesi için, bir kaç defter değiştirerek en az altı aylık bir sürede kurutabilmektedir. Bu ön hazırlık dönemi Erdoğmuş'un emek yoğun resimlerinin alt yapısını uzun süreçlerde oluşturduğunu göstermektedir. Kurutulmuş bitkileri tuval üzerine akrilik bir malzeme ile uygulayan Erdoğmuş, aynı yaklaşımı katmanlar halinde sürdürmektedir (Resim 11). Tuval üzerine yaklaşık yüzelli katmana varan yoğun bir emek süreciyle resim tamamlanmaktadır. Tayfun Erdoğmuş çalışmalarını kısaca "Konvensyonel olmayan bir pentür, pentür gibi olmayan bir pentür" (26) cümleleriyle açıklamaktadır.
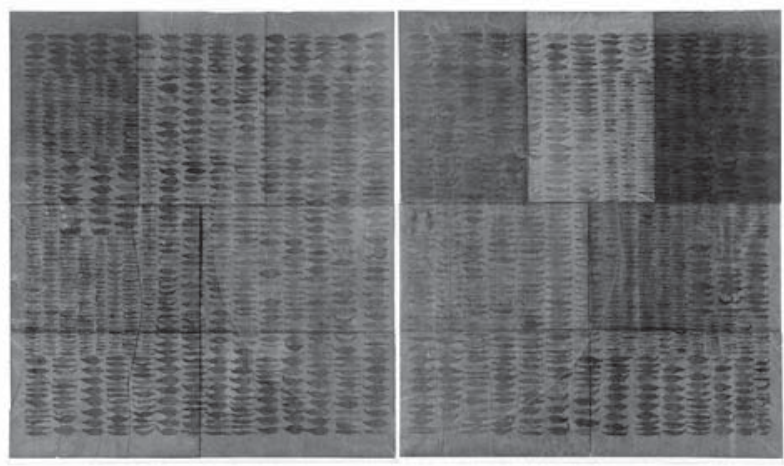

Resim 11. Tayfun Erdoğmuş, Tuval üzerine karışık teknik, 230x390 cm., 2008, Tayfun Erdoğmuş ve Galeri Nev'in izniyle.

Tuvallerinde boyanın yerini pirinç, gümüş ya da bakır varaklar almaktadır. Varakları nemli ortamda bırakarak, buharla ve başka kimyasallarla eskitmektedir (Resim 12). Bu malzemeler Erdoğmuş'un istediği renge dönüşmektedir. Bu bilgilerini Tatbiki'de almış olduğu eğitime dayandırmakta olan Erdoğmuş, Tatbiki eğitimini “... Örneğin gravür metal kalıba resmi kazırken bakır plakanın nasıl aşındırılacağını öğreniyorsun; kesmeden aşındırmaya, metalin oksitlenmemesine kadar bir çok teknik sürece hakim oluyorsun, aynı süreçte başka projelerin için camla, kumla, sıvayla da çalışabiliyorsun. Çeşitli malzeme kullanımları, teknik deneyimler ve bilgiler farklı atölye ve hocalardan öğrenilir. 0 nedenle eğitim tek bir atölye odaklı değildir, neredeyse birbirinden bağımsız gibi duran bilgi alanlarından öğrencilerin biriktirdikleriyle bireysel bir yapı oluşturmaları hedeflenir. Bauhaus okullarıyla Görsel Sanatların temel öğelerinin aktarımı Temel Sanat Eğitimi dersleri ile elemanter bir yapıya kavuşmuştu. Nokta, çizgi, renk, doku, vb. elemanların dans, müzik ve edebiyat gibi diğer sanat alanlarıyla da ilişkilendirilerek verilmiştir. Aslında bu elemanter yapı eğitim modelimizin temelini oluşturur ve atölye yaklaşımlarından bağımsız olarak öğrencinin kendi özgün dilini kurmasını hedefler..." (27) sözleriyle anlatmaktadır. 

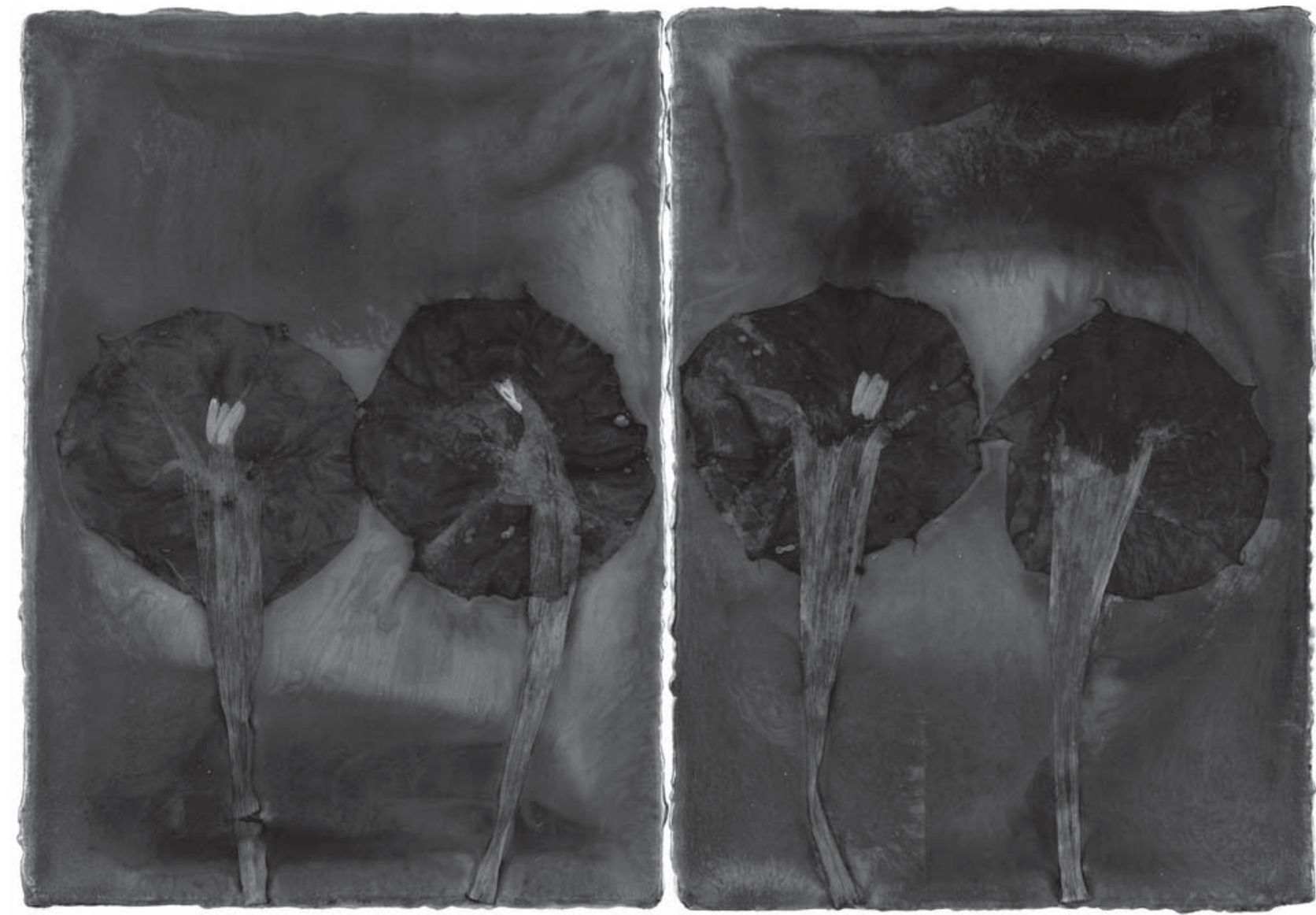

Resim 12. Tayfun Erdoğmuş, Tuval üzerine karışık teknik, 31 x44cm., 2009, Tayfun Erdoğmuş ve Galeri Nev'in izniyle.

Farklı bir disiplinden gelmesine karşın, Erdoğmuş ve Koçan gibi,

Tatbiki'nin çatısı altında verilen yetkin sanat eğitimine çalışmaları temelIenen Murat Morova, malzemelere kendine özgü kişisel yaklaşımıyla Türk Resim Sanatında farkı bir duruşla yer almaktadır. 1976 yılında Tatbiki Güzel Sanatlar Yüksek Okulu İç Mimarlık Bölümü'nden birincilikle mezun olan Morova 90'ların başına kadar İç Mimar olarak çalışır ancak 80'lerin sonunda 0 yılların siyasal karmaşası, baskısı ve yeni para kazanan sınıf ile arasındaki görüş farklılıkları, Morova'ya 'Yeni bir hayat olabilir mi sanat?' sorusunu sordurur. Radikal bir karar ile alan değiştirerek sanatsal yolculuğuna başlar. "Çok özgürdüm, bu özgürlüğümü neye borçluyum? 0 özgürlüğü Akademi kökenli olmamaya borçluyum belki... Tasarım dünyasından gelmek kendimi malzeme kullanımında çok özgür hissettirdi. Sonra gene okul dönemini gözden geçirirsek; çok iyi bir Temel Sanat Eğitimi aldık. 0 dönemin Temel Sanat hocası Mümtaz Işıngör'ü büyük bir vefa borcuyla anmak isterim. Hem geleneksel teknikleri gösteren, desene önem veren, hem de üç boyutlu işler yaptıran, malzeme kullanımını özgür bırakan... Kurum küçük olduğundan bölümler arası hiyerarşik bir yapı yoktu. Dersin olmadığı bir gün bir resim atölyesine gidersin, hoca gelir, senin ne işin var? demez. Tatbiki'den toparladığım izlenimler çok değerli. Şimdi geriye dönüp baktığımda, tekstilden seramiğe, fotoğrafdan resime, iç mimarlık atölyesinden ağaç bilemeye... Tatbiki'nin bu yapısının çok faydasını gördüğümü düşünüyorum" (28).
Murat Morova, 1998 yılında Urart Sanat Galerisi'nde açmış olduğu ‘Dil ve Suret' sergisinde kendi güncesi üzerinden dervişlerin çilehaneye girdiklerinde yazdıkları yazıların şemaları ile ilgili çalışmaktadır. Bu sergi hem anlatım dili olarak hem de malzeme anlamında Morova'nın işlerinde bir milat noktası olmaktadır. Morova bu sergisi hakkında, "DilSuret sergisinde farklı malzemeler kullandığım ilk sergiydi. El yapımı kâğıtlar, cam, kaligrafi bu sergimde kullandığım malzemelerdi.... Bütün kullandığım malzemelerde bir şekilde hep bir geçicilik duygusu var. Bir paslanmışlık, bir çürüme... Zamanı kendi içinde de gösterebilecek olan malzemelere karşı da bir zaafım var" (29) demektedir.

Sanatçının 2007 yılında Galeri Nev, İstanbul'da açmıs olduğu 'Menazir-i Mensiyye' sergisi bir yolculuk hikayesidir (Resim 13). Sanatçı yolculuk kavramıyla ilgilenirken seyehatnameleri incelemekte, bunların estetik dile dönüşümünü araştırmakta ve kendi deyimi ile harikulade bir eser olan 'Sefer-i Irakeyn'i incelemektedir. Morova Matrakçı Nasuh'un estetiğinde; aynı kadraj içindeki bazı şeylerin klasik perspektife uygun oluşunu, bazı şeylerin ise kuş bakışı duruşunu, kendi dünyayı algılama şekline yakın bulmaktadır. Matrakçı Nasuh minyatürleri ile kendi yaşama bakışı ve seçiciliği arasında paralellik kurmaktadır. Bunun üzerine sergiyi atölyede kurgulamak yerine Matrakçı Nasuh gibi gerçek bir yolculuğa çıkar. Bu yolculukta Matrakçı'nın güzergahından farklı bir yol çizmektedir. 

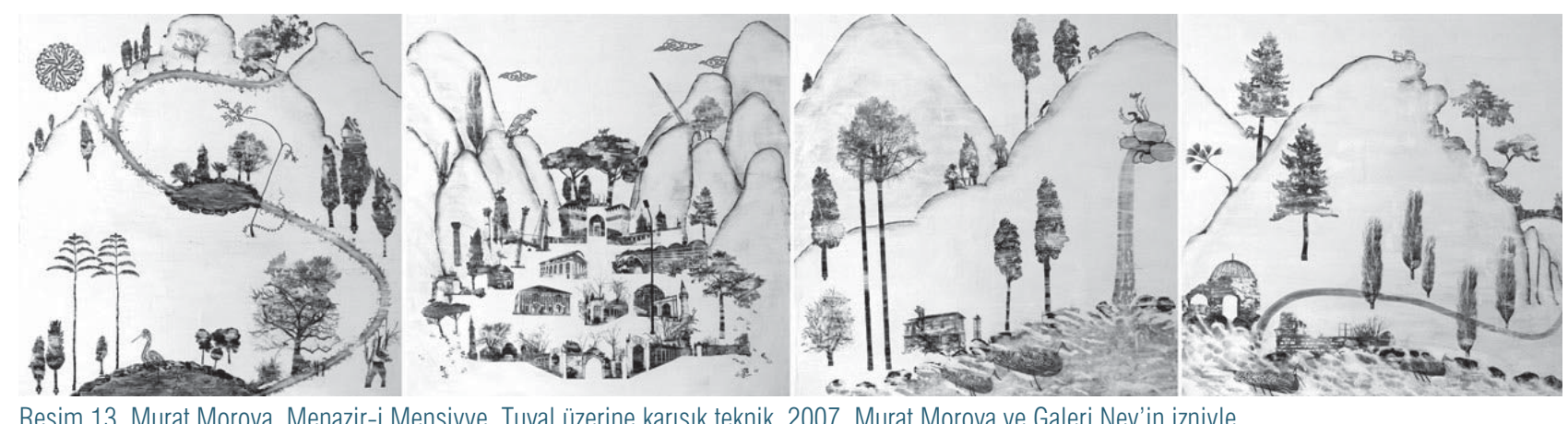

Resim 13. Murat Morova, Menazir-i Mensiyye, Tuval üzerine karışık teknik, 2007, Murat Morova ve Galeri Nev'in izniyle.

"Ankara'da Hacı Bayram ile başlar, Taptuk Emre, Yunus Emre, Hasan Dede Mevlevii ile devam eder. Bu ülkenin kültür, tefekkür ve inanç tarihinde yer almış önemli aktörlerin izini sürmekti." (30) Morova, Matrakçının mantığında olsa da yolculuk boyunca geçtiği yerlerde değişen koșullarını, vinçleri, viyadükleri, beton makinalarını fotograflamaktadır (Resim 14). Murat Morova,“... Hayatın hem değişmeyen yanı, hayatın hem değişen yanı. Bu iki nokta bizim duygularımızın, estetiğimizin bir arafta olma hali üstüne bir çalışma yaptım..." (31) demektedir.

Yolculuk sonrası çektiği fotografları dijital ortamda değiştirmektedir. Photoshop kullanarak fotografların grenlerini artırmakta, siyah-beyaza çevirmekte, asetatlara bastırmaktadır. Bu saydam tabakalar aynı bir Kat'ı titizliğinde kesilmektedir. Sanatçı asetatları saydam yapılarını öne çıkaracak biçimde tuvalle birleştirmektedir.

Murat Morova tuval yüzeyini fresko etkisine getirebilmek için yapı işlerinde kullanılan alçı ile plastik arası macunumsu emici bir malzemeyi keşfetmiştir. Yüzeye desenlerini başat malzemesi olan katranla uygulamaktadır. "Renk ve türevlerini çok sevdiğim katran neredeyse çoğu ișimde var. Bu seride katranın selülozik tinerle tonalitelerini olușturdum" (32). Tuval yüzeyine uyguladığı kalın dokulu malzeme katranı emmekte, freskoda olduğu gibi bir darbe alsa bile alt katmana da boya geçtiğinden desen bozulmamaktadır.

Yüzeye uyguladığı malzemeyi, yapıştırımış asetatları, keçeli kalemle ve katranla uyguladığı desenleri sabitlemek için lak kullanmaktadır. Lak, Morova'nın yapıtlarını Uzak Doğu estetiğinde kullanılan Çin lakesi panolara yaklaşıırmaktadır. Morova yapıılarını "Malzeme, düşünce, estetik, üçü biraraya gelerek bir şekilde referans veren bir duygu ortaya çıkardı."(33) cümlesi ile özetlemektedir.

Morova kaligrafik örnekleri kullanmakta ancak bunların bir süsleyici öğeden çok bir anlam içerisinde olmasına çalışmaktadır. "Geleneğe bir malzeme deposu olarak bakmak istemiyorum... Ben ilhama dayalı bir sanatçı değilim, benim için öncelikli olan bir kavram var, onu öne alıyorum. Bir malzeme fetişizmim de yok. Bazı insanlar vardır, malzemeyi çok sever sonra ben bu malzemeyle neler yapabilirim der. Benim için malzeme düşünceme hizmet eder..." (34) sözleri Morova'nın malzeme resmine yaklaşımını göstermektedir.

Morova'nın Menazir-i Mensiye resimleriyle Ankara- İstanbul seyahatini

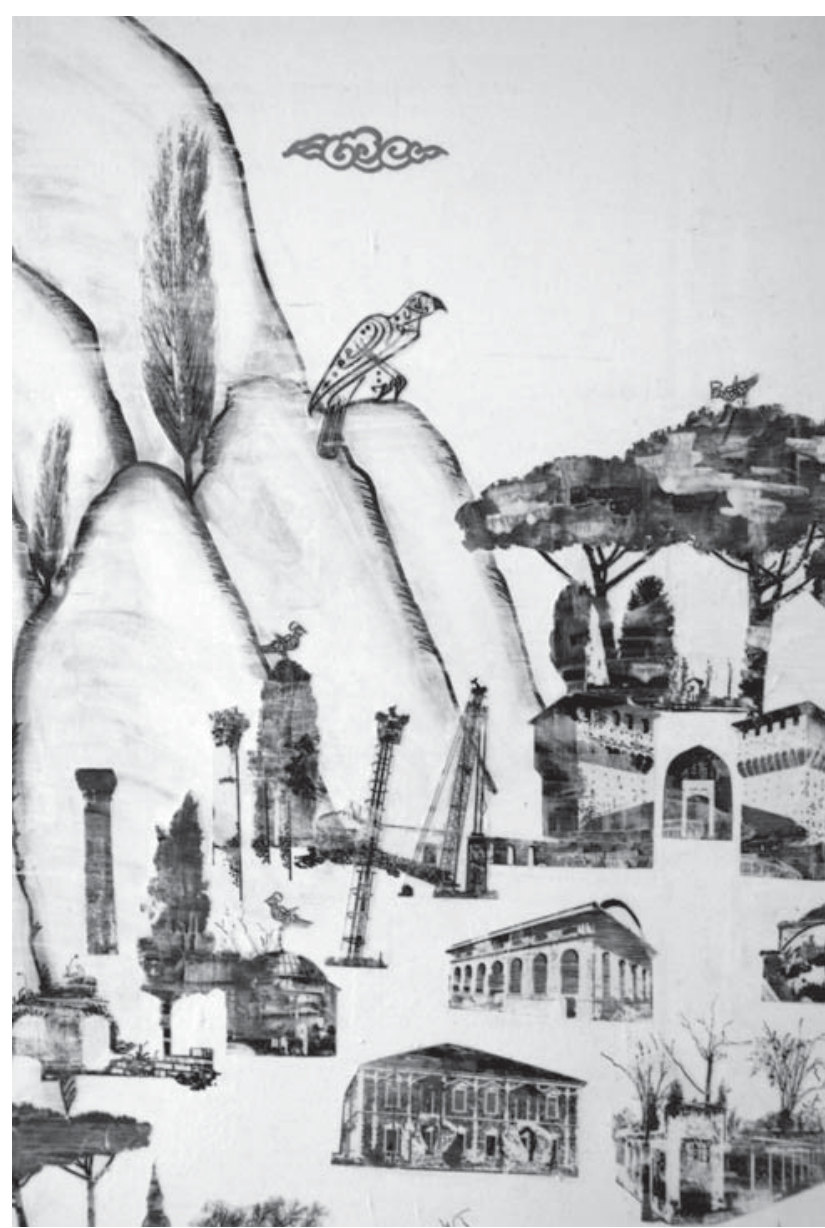

Resim 14. Murat Morova, Menazir-i Mensiyye, Tuval üzerine karışık teknik, 2007, Murat Morova ve Galeri Nev'in izniyle.

önümüzden bir film şeridi gibi geçirmektedir. Morova'nın bu resimleri, izlediği durum ve olayın görüntülerini Batı resminde olduğu gibi naturalist bir bakış açısından objektif olarak yansıtmamaktadır. Tam tersine Osmanlı nakkaşları gibi duygularına dayanan öznel yorumlar getirmektedir.

Bu çalışma doğrultusunda incelenen Tatbiki kökenli sanatçıların tuval üzerinde geleneksel malzemenin dışındaki olanaklarla yapıtlarını ürettikleri görülmektedir. Devlet Tatbiki Güzel Sanatlar Yüksek Okulu ve 
TABLO 1

\begin{tabular}{|c|c|c|}
\hline Öğretim Üyeleri & Desler* & $\begin{array}{l}\text { Çalıştığı } \\
\text { Yillar }\end{array}$ \\
\hline Herwig Schubert (d.1926) & Serbest Resim (Buluș Kompozisyon) Dersi & $1957-1962$ \\
\hline Hans Bauerle (d.1931) & Duvar Dekorasyonu ve Tatbikatı & $1958-1962$ \\
\hline Mazhar Resmor (d.1901-ö.1977) & Vitray & $1958-1962$ \\
\hline Erol Eti (d.1936) & Serbest Resim (Buluș Kompozisyon)/ Resim Sanatı & $1962-2001$ \\
\hline Mustafa Pilevneli (d.1940) & Malzeme Bilgisi/ Duvar Resmi & $1962-2002$ \\
\hline Metin Şahinoğlu (d.1936) & Serbest Resim (Buluș Kompozisyon)/Resim Sanatı & $1962-2002$ \\
\hline Walter Schimph (d.1928) & Malzeme Bilgisi & 1963-1969 \\
\hline Bernard Müller & Serbest Resim (Buluș Kompozisyon)/ Resim Sanatı & $1963-1965$ \\
\hline Nevzat Yüzbașığlu (d.1938) & Malzeme Bilgisi/ Malzeme Resmi & $1963-2002$ \\
\hline Helmut Hungerberg (d.1935) & Serbest Resim (Buluş Kompozisyon)/ Resim Sanatı & $1965-1971$ \\
\hline Oktay Maral (d.1940) & Malzeme Bilgisi/ Cam Resmi & 1966-1994 \\
\hline İlyas Ergin İnan (d.1943) & Serbest Resim (Buluş Kompozisyon)/ Resim Sanatı & $1968-1998$ \\
\hline Sema (Arıman) Arıgil (d.1944) & Malzeme Bilgisi/ Halı Resmi & 1973-2004 \\
\hline Balkan Naci İslimyeli (d.1947) & Resim Sanatı & 1973-1999 \\
\hline Hüsamettin Koçan (d.1946) & Serbest Resim (Buluș Kompozisyon)/ Resim Sanatı & $1975-2006$ \\
\hline Kadri Özaten (d.1947-ö.2014) & Serbest Resim (Buluș Kompozisyon)/ Resim Sanatı & 1975-1999 \\
\hline Cevat Demir (d.1946) & Malzeme Bilgisi/ Cam Sanatı & $1975-2006$ \\
\hline Filiz Başaran (d.1951) & Serbest Resim (Buluș Kompozisyon)/ Resim Sanatı & 1978- \\
\hline Kemal Gürbüz (d.1949) & Malzeme Bilgisi/ Malzeme Resmi & 1978- \\
\hline Tayfun Erdoğmuş (d.1958) & $\begin{array}{l}\text { Serbest Resim (Buluş Kompozisyon)/ Resim Sanat1- } \\
\text { Özgün Baskı Resim }\end{array}$ & 1981- \\
\hline Mürteza Fidan (d.1963) & Resim Sanat1- Özgün Baskı Resim & 1988- \\
\hline Devabil Kara (d.1962) & Resim Sanat1- Duvar Resmi & 1988- \\
\hline Kerim Kılıçaslan (d.1963) & Resim Sanat1- Duvar Resmi & 1992- \\
\hline Sevil Sayg1 (d.1967) & Malzeme Resmi & 1992- \\
\hline Zafer Mintaş (d.1965) & Resim Sanat1- Özgün Baskı Resim & $1992-$ \\
\hline Hakan Onur (d.1965) & Cam Sanatı & 1995- \\
\hline Rüçhan Șahinoğlu Altınel (d.1970) & Resim Sanatı & 1995- \\
\hline Elif Çelebi Taktak (d.1973) & Resim Sanatı & $2000-$ \\
\hline
\end{tabular}

*TGSYO'nun kuruluş yıllarındaki ders adları ve MÜGSF'deki güncel ders adları kullanılmıştır. Bu tarihler arasındaki ders adı değişiklikleri tabloda gösterilmemiştir. 
Marmara Üniversitesi Güzel Sanatlar Fakültesi mezunları hakkında Esra Aliçavuşoğlu, "Özellikle 70'lerden sonra çağdaş Türk sanat ortamında gözlemlediğimiz çoğulcu görüşlerin, malzeme çeşitliliğinin, deneysel yaklaşımların, arayışların ve dolayısıyla Tatbikili ya da güncel adıyla Marmaralı sanatçıların da büyük etkisi olduğu ifade edilebilir” (35) demektedir.

Tatbiki ve Marmara mezunu sanatçılar, diğer alanlarda olduğu gibi teknoıji çağının ekonomik, toplumsal, siyasal ve kültürel olaylarını da kendi alanlarına ait materyallerle tuvallerine yansıtmışlardır. Bu üç sanatçının kavramla şekillenen yapıtları Dekoratif Resim Bölümü'nün değişerek günümüz sanatıyla koşut güncel içeriğini yansıtmaktadır. Geleneksel teknikleri anlatım dilinde yetersiz bulan bu üç sanatçı, tuvallerinde geleneksel olmanın ötesine geçerek, malzeme ve teknik yorumlarla yeni üretimlere girmişlerdir.

Bauhaus geleneğinin etkisiyle kurulmuş olan Tatbiki Güzel Sanatlar Yüksek Okulu eğitiminde deneysel eğitim sistemi sanatçıların malzeme seçimindeki özgürlüğü ile sonuçlanmıştır. Tatbiki Güzel Sanatlar Yüksek Okulu eğitiminin verdiği malzeme kullanımındaki serbestlik ve deneysellikle sanatcıların ister tuvallerinde isterse mekâna yayılan işlerinde farklı üretim biçimlerine yakınlıkları gözlemlenmektedir.

Çalışmada ele alınan üç sanatçının tuvallerinde yeni ve farkı malzeme kullanımına olan yakınlıkları Tatbiki Güzel Sanatlar Yüksek Okulu'yla başlayan, Marmara Üniversitesi Güzel Sanatlar Fakültesi Resim Bölümü’yle süren deneysel eğitim modelinin sanatsal yansıması olduğu söylenilebilir.

\section{*Doç. Z. Rüçhan Şahinoğlu Altınel}

Marmara Üniversitesi Güzel Sanatlar Fakültesi, Resim Bölümü

Küçük Çamlıca, 34718, Acıbadem, Kadıköy/ İstanbul

E-posta: zrsahinoglu@yahoo.com

\section{Dipnotlar}

1. Artun, Ali; 2009, Türkiye'de Mimarlık, Sanat, Tasarım Eğitimi ve Bauhaus, Bauhaus: Modernleşmenin Tasarımı Türkiye'de Mimarlık, Sanat, Tasarım Eğitimi ve Bauhaus, İletişim Yayınları, s.13.

2. T.C. Milli Eğitim Bakanlığı Mesleki ve Teknik Öğretim Müsteşarlığı, İstanbul Tatbiki Güzel Sanatlar Okulu Yönetmeliği, 1961, Baha Matbaası, s.1

3. Antmen, Ahu; 2008, Sanatçılardan Yazılar ve Açıklamalarla 20. Yüzyıl Batı Sanatında Akımlar, İstanbul, Sel Yayıncılık, s.107.

4. Bayer, Herbert; Gropius, Walter; Gropius, Ise; 1990, Bauhaus, 1919-1928, Newyork, The Museum of Modern Art, s.24

5. Antmen, Ahu; 2008, Sanatçılardan Yazılar ve Açıklamalarla 20. Yüzyıl Batı Sanatında Akımlar, İstanbul, Sel Yayıncılık, s.107.

6. Köksal, Duygu; 2009, Cumhuriyet İdolojisi ve Estetik Modernizm: Baltacıoğlu, Yeni Zamanlar ve Bauhaus, Bauhaus: Modernleşmenin Tasarımı Türkiye'de Mimarlık, Sanat, Tasarım Eğitimi ve Bauhaus, Illetişim Yayınları, s.256.

7. Gürsel, Barbaros; 2009, Bauhaus'un Fotoğraf Sanatına Etkisi, Bauhaus: Modernleşmenin Tasarımı Türkiye'de Mimarlık, Sanat, Tasarım Eğitimi ve Bauhaus, Ilıtişim Yayınları, s.450.

8. 14.05.2014 tarhli Frank Metzger'in yayınlanmamış mektubundan

9. T.C. İstanbul Tatbiki Güzel Sanatlar Yüksek Okulu Eğitim-Öğretim Planları, 1973, Talim ve Terbiye Kurulu, s. I.

10.Aliçavuşoğlu, Esra; 2009, Bauhaus Geleneği ve Günümüz Sanatına Yansımaları, Bauhaus: Modernleşmenin Tasarımı Türkiye'de Mimarlık, Sanat, Tasarım Eğitimi ve Bauhaus, Illetişim Yayınları, s.24
11. T.C. İstanbul Tatbiki Güzel Sanatlar Yüksek Okulu Eğitim-Öğretim Planları, 1973, Talim ve Terbiye Kurulu, s. 4.

12.T.C. İstanbul Tatbiki Güzel Sanatlar Yüksek Okulu Eğitim-Öğretim Planları, 1973, Talim ve Terbiye Kurulu, s. 5.

13.Ak, Bircan; 2008, Sanat ve Tasarım Eğitiminde Tatbiki Güzel Sanatlar Gerçeği, MÜGSF Yayınları, s.49.

14.T.C. İstanbul Tatbiki Güzel Sanatlar Yüksek Okulu Eğitim-Öğretim Planları, 1973, Talim ve Terbiye Kurulu, s. 5.

15.Aslıer, Mustafa; 1972, Henüz Var OImayan Şeye Biçim Vermek, İstanbul Devlet Tatbiki Güzel Sanatlar Yüksek Okulu Broșürü, s.5.

16. Mayıs 2014 tarihli Hüsamettin Koçan ile yapılan yayınlanmamış söyleşiden alınmıştır

17. Yasa Yaman, Zeynep; 2005, Hüsamettin Koçan Yedi Sergi Bir Selamlama, İstanbul, Baks Kültür Sanat Vakfı, s.31.

18. Yasa Yaman, Zeynep; 2005, Hüsamettin Koçan Yedi Sergi Bir Selamlama, İstanbul, Baks Kültür Sanat Vakfı, s. 45.

19. Yasa Yaman, Zeynep; 2005, Hüsamettin Koçan Yedi Sergi Bir Selamlama, İstanbul, Baks Kültür Sanat Vakfı, s.64.

20.Mayıs 2014 tarihli Hüsamettin Koçan ile yapılan yayınlanmamış söyleşiden alınmıştır.

21.Aliçavuşoğlu, Esra; 2010, Uzak Mekân Hüsamettin Koçan, İstanbul, Baksı Kültür ve Sanat Vakfı, s.158.

22.Mayıs 2014 tarihli Hüsamettin Koçan ile yapılan yayınlanmamış söyleşiden alınmıştır. 23. Haziran 2014 tarihli Tayfun Erdoğmuş ile yapılan yayınlanmamış söyleşiden alınmıştır.

24. Haziran 2014 tarihli Tayfun Erdoğmuş ile yapılan yayınlanmamış söyleşiden alınmıştır.

25.Aliçavuşoğlu, Esra; 2008, Tayfun Erdoğmuş’un 'Naturalist Üslupta' Tuvalleri, Cumhuriyet Haftasonu, 15 Mart 2008, s.2.

26. Haziran 2014 tarihli Tayfun Erdoğmus ile yapılan yayınlanmamıș söyleșiden alınmıștır.

27. Haziran 2014 tarihli Tayfun Erdoğmuş ile yapılan yayınlanmamış söyleşiden alınmışıı

28. Nisan 2014 tarihli Murat Morova ile yapılan yayınlanmamış söyleşiden alınmıştır.

29.Nisan 2014 tarihli Murat Morova ile yapılan yayınlanmamış söyleşiden alınmışır.

30. Nisan 2014 tarihli Murat Morova ile yapılan yayınlanmamış söyleşiden alınmışıı.

31. Nisan 2014 tarihli Murat Morova ile yapılan yayınlanmamış söyleşiden alınmıştır.

32. Nisan 2014 tarihli Murat Morova ile yapılan yayınlanmamış söyleşiden alınmıştır.

33.Nisan 2014 tarihli Murat Morova ile yapılan yayınlanmamış söyleşiden alınmıștır.

34. Nisan 2014 tarihli Murat Morova ile yapılan yayınlanmamış söyleşiden alınmışır.

35.Aliçavuşoğlu, Esra; 2009, Bauhaus Geleneği ve Günümüz Sanatına Yansımaları, Bauhaus: Modernleşmenin Tasarımı Türkiye'de Mimarlık, Sanat, Tasarım Eğitimi ve Bauhaus, İletişim Yayınları, s.25

\section{Kaynaklar}

- Artun, Ali; 2009, Türkiye'de Mimarlık, Sanat, Tasarım Eğitimi ve Bauhaus, Bauhaus: Modernleşmenin Tasarımı Türkiye'de Mimarlık, Sanat, Tasarım Eğitimi ve Bauhaus, Illetişim Yayınları.

- T.C. Milli Eğitim Bakanlığı Mesleki ve Teknik Öğretim Müsteşarlığı, İstanbul Tatbiki Güzel Sanatlar Okulu Yönetmeliği, 1961, Baha Matbaası.

- Antmen, Ahu; 2008, Sanatçılardan Yazılar ve Açıklamalarla 20. Yüzyıl Batı Sanatında Akımlar, İstanbul, Sel Yayıncılık.

- Bayer, Herbert; Gropius, Ise; Gropius, Walter; 1990, Bauhaus, 1919-1928, Newyork, The Museum of Modern Art.

- Köksal, Duygu; 2009, Cumhuriyet İdolojisi ve Estetik Modernizm: Baltacıoğlu, Yeni Zamanlar ve Bauhaus, Bauhaus: Modernleşmenin Tasarımı Türkiye'de Mimarlık, Sanat, Tasarım Eğitimi ve Bauhaus, Illetişim Yayınları.

- Gürsel, Barbaros; 2009, Bauhaus'un Fotoğraf Sanatına Etkisi, Bauhaus: Modernleşmenin Tasarımı Türkiye'de Mimarlık, Sanat, Tasarım Eğitimi ve Bauhaus, Iletişim Yayınları.

- 14.05.2014 tarhli Frank Metzger'in yayınlanmamış mektubundan

- T.C. İstanbul Tatbiki Güzel Sanatlar Yüksek Okulu Eğitim-Öğretim Planları, 1973, Talim ve Terbiye Kurulu.

- Aliçavuşoğlu, Esra; 2009, Bauhaus Gelleneği ve Günümüz Sanatına Yansımaları, Bauhaus: Modernleşmenin Tasarımı Türkiye'de Mimarlık, Sanat, Tasarım Eğitimi ve Bauhaus, Illetişim Yayınları.

- Ak, Bircan; 2008, Sanat ve Tasarım Eğitiminde Tatbiki Güzel Sanatlar Gerçeği, MÜGSF Yayınları.

- Aslıer, Mustafa; 1972, Henüz Var OImayan Şeye Biçim Vermek, İstanbul Devlet Tatbiki Güzel Sanatlar Yüksek Okulu Broşürü.

- Mayıs 2014 tarihli Hüsamettin Koçan ile yapılan yayınlanmamış söyleşi. 
- Yasa Yaman, Zeynep; 2005, Hüsamettin Koçan Yedi Sergi Bir Selamlama, İstanbul, Baksı Kültür Sanat Vakfı.

- Aliçavuşoğlu, Esra; 2010, Uzak Mekân Hüsamettin Koçan, İstanbul, Baksı Kültür ve Sanat Vakfı.

- Haziran 2014 tarihli Tayfun Erdoğmuş ile yapılan yayınlanmamış söyleşi.

- Aliçavuşoğlu, Esra; 2008, Tayfun Erdoğmuş'un 'Naturalist Üslupta' Tuvalleri, Cumhuriyet Haftasonu, 15 Mart 2008.

- Nisan 2014 tarihli Murat Morova ile yapılan yayınlanmamıs söyleși. 